\title{
The Master Problem of the Age: Print Culture and the Sex Trade in Canada, 1880-1920
}

\begin{abstract}
An historical case study of the moral panic which characterized anti-prostitution efforts in late nineteenth- and early twentieth-century Canada both on and off the page provides evidence for the influence print media can have on social thought and marginalizing practices. A selection of reformist publications is examined to highlight parallels that existed between print media and common attitudes towards and regulation of the sex trade. One significant parallel is a tendency to interpret the trade as rooted in the perceived moral and behavioural aberrancies of young wage-earning women. Various developments in print and information culture during this period are then explored to suggest why such commonalities may have existed. An ever-deepening connection between Canadian society and the printed word increased the ability of print material to reach and influence the general public. This connection offers a possible explanation for similarities in attitude towards female sex workers in print and in reality, which serves as an example of the printed word's strong potential for social influence.
\end{abstract}

Keywords: information history, print culture, sex trade, reform,

About the Author(s): Jannaya Jensen is a student in the Master of Library and Information Studies program (Candidate 2014) at Dalhousie University. A former History student at the University of Saskatchewan, she has a special interest in applying this background to her current academic work through the study of information history. Jannaya completed this paper for INFO 5500 Information in Society, a course offered by Dalhousie's School of Information Management. 


\section{Introduction}

Creators and providers of printed material can play a significantly influential role in general society, stimulating progressive thought as well as reinforcing existing prejudices. A text can shape the way that its readers view a group of people by how it examines and characterizes them. Information professionals must be mindful of this reality and the fact that the profession may, at times, present ethical dilemmas if it requires them to provide access to materials that have the potential to perpetuate marginalizing practices.

The potentially adverse influence of the printed word is explored in an historical case study of reformist literature and print culture in late nineteenth-century and early twentieth-century Canada. During this period of Canadian history, the sex trade was seen as "the master problem of the age - 'the social evil'" (Strange \& Loo, 1997, p. 63). This attitude characterizes what Myers (2001) refers to as "Canada's first major reform period" (p. 228). Spanning from 1880 to the 1920s, reformers were particularly active in addressing and challenging the growth of Canada's sex trade and red-light districts (Myers, 2001, p. 228). Toronto's attack on the trade is especially notable, given its scale in comparison to other Canadian cities (Strange, 1995, p. 145). Various groups in Toronto and other cities focused on the perceived moral and behavioural deficiencies of sex workers as the root cause of the trade (Rotenberg, 1974, p. 52). Similar attitudes are reflected in reformist literature from the time period, including Of Toronto the Good, first published in 1898 (Clark, 1970), Canada's War on the White Slave Traffic (Shearer \& Moore, 1911), Report of the Social Survey Commission (Toronto, 1915) and Report of the Royal Commission on the Relations of Capital and Labor (Canada, Armstrong \& Freed, 1889).

In order to understand these similarities in attitude better, the function of this paper is twofold. First, the content of such print materials will be analyzed to highlight the parallels that existed between the printed portrayal of the trade and Canadian attitudes toward, and regulation of, the trade. Second, a study of print and information culture during this period will suggest why these parallels may have existed.

Several scholars have acknowledged the challenge of assessing the influence of published material on general society. Towheed, Crone, and Halsey note that, while the study of such topics as print and information culture can "empirically map out the metrics of the domain of reading... [it] cannot offer us a complete picture of how individual readers interacted with specific books" (2011, p.2). Similarly, Lyons 
emphasizes that a "reader is not an empty or transparent receptacle who automatically receives the 'imprint' of what is read. Readers select, interpret, re-work, and re-imagine what they read" $(2010$, p. 3). Therefore, in the following study, I will attempt to assess the significance of the texts under consideration with appropriate caution. In the absence of primary sources documenting individual readers' reception of this literature, it cannot be concluded with certainty how, exactly, these texts were perceived. However, the following study is nevertheless relevant insofar as it begins to highlight the potential ability of printed material to impact social thought and marginalizing practices. Developments in the print and information systems of late nineteenth- and early twentieth-century Canada fostered a strong connection between the printed word and the lives of Canadians (Parker, 2005, p. 17). This strengthened connection suggests that the parallels between reformist literature and societal attitudes towards the sex trade may not have been purely incidental. Rather, as such texts existed in an era in which print material's ability to influence society was experiencing tremendous growth, these parallels more likely provide evidence of how the printed word can have a direct impact on social thought and attitudes.

\section{General Attitudes and Regulation}

Various scholars of Canadian women's history have highlighted the fact that blame for the growth of the sex trade during this period was often focused on the women who worked as prostitutes. Moral reformists did not refer to the sex trade as "the social evil" in order to characterize the trade as a result of social marginalization or inequality. Rather, the term was used to refer to the supposed moral deviancy of the individuals involved in the trade (Rotenberg, 1974, p. 33). A common general attitude toward women during this period was that they were more "predisposed toward deviance" than men, specifically with regard to sexuality (Chunn, 2003, p. 196). As an expression of this attitude, certain sectors of society tended to focus the blame for "the social evil" not on procurers (more commonly known as "pimps"), but on the female sex workers themselves.

Certain women's organizations frequently reflected this focus on female moral or behavioural aberrancy as the cause of the trade. The Toronto Council of Women, for example, maintained that the sexual ignorance and naiiveté of young women was the base cause of the trade (Rotenberg, 1974, p. 43). Alternatively, the Big Sisters focused on "the temptations of urban life" for young women as being primarily responsible (Strange, 1995, p. 127). These attitudes broadly classified female sex workers as either intellectually deficient or too easily swayed by the offerings of city life. Similar attitudes toward female behaviour were reflected in other urban localities. For 
example, Montreal's Committee of Sixteen, formed in 1918 to study "commercialized vice," focused on the female "sexual delinquent" as the driving force behind the trade (Myers, 2001, p. 229).

These groups neglected to highlight the broader societal and economic conditions that often drove women into this line of work. Even the lowest-paid male labourer received a higher wage than female workers, who lived "a hand-to-mouth existence" (Strange, 1995, p. 25-26). Some groups, such as a 1913 University of Toronto research team, determined that the poverty experienced by female workers was a significant "precondition to prostitution" (Strange, 1995, p. 120). However, whether they emphasized ignorance, impressionability, or sexual deviancy as the primary "female flaw," other groups, such as those noted above, asserted that character defects in young women were the root causes of the trade. To them, the solution to "the social evil" was not in economic reform, but rather in individual moral improvement and behavioural modification.

Further evidence of this attitude toward the sex trade and its causes can be found in an examination of the treatment that female sex workers, and young women in general, often received from the justice system. By the early twentieth century, several North American cities were hiring female officers onto their urban police forces. These officers were hired explicitly for the purpose of policing and managing the conduct of the city's young women and girls (Myers, 2001, p. 229). Such a development highlights that special concern for the behaviour of young females extended beyond women's organizations and into other spheres of society.

Emphasis on policing women's behaviour is also demonstrated by the fact that, in numerous Canadian cities, the majority of prostitution-related arrests and convictions during this time period were of women (Strange \& Loo, 1997, p. 54). For example, from 1912 to 1917. the Vancouver police force arrested a total of 332 women under the charge of "keeping houses of ill fame" (Strange \& Loo, 1997. P. 54). In contrast, only twenty-nine men received a similar charge and only seven were arrested as procurers (Strange \& Loo, 1997, p. 83). During the height of Toronto's moral reform period, arrest statistics for each year, less one, demonstrate an inclination in the police force to consider male clients of prostitutes "less culpable participants in heterosexual commerce" than the women who worked as prostitutes (Strange, 1995, p. 146). According to the figures listed by Strange on prostitution-related arrests from 1880 to 1920, arrests of females in Toronto made up an average of 76.2 per cent of total prostitution-related arrests (Strange, 1995, p. 223). This percentage suggests that 
the police force viewed the control of women as the most effective means of regulating the trade.

Focus on the individual responsibility of women in the sex trade was upheld in the courtroom, as well (Prentice et al., 1996, p. 161). Surviving court cases show that women and girls facing delinquency charges tended to be more heavily penalized than men and boys facing similar charges (Chunn, 2003, p. 199). In the unusual case that a male client of the sex trade was actually charged, he was typically handed a fine (Strange, 1995, p. 147). In contrast, women found guilty of prostitution-related offences were sentenced to prison terms ranging from a few months up to a decade (Strange, 1995, p. 133). From women's organizations and the justice system to society in general, discriminatory attitudes towards female sexuality and proper behaviour played a significant role in shaping the ways in which female sex workers were viewed, treated, and regulated.

\section{The Role of Print Media in the Reformist Cause}

Print media was one means through which reformists expressed their views on "the social evil" and its causes. In McCormick's (1995) transcription of a talk given by lawyer Anne Derrick on a more recent study of the depiction of sex work in Canadian media, Derrick discusses the "legitimation that goes along with being heard in the media." Derrick highlights the common notion that "if you are heard, if you are speaking out, if you are being reported, then you must have something that is worth saying or something that is worth listening to" (Derrick, n.d., as cited in McCormick, 1995, pp. 38-39). According to this argument, the fact that reformists succeeded in publishing many of their ideas regarding the sex trade gave credence to their remarks, which could have influenced certain individuals to accept the information as valid.

McKillop (2007) discusses that another way in which print media influences its audience is by its ability to present lengthy and complex examinations of a topic, which allows the information to become more deeply embedded in the minds of its audience (p. 13). Because of this ability, print plays a "fundamental role as a medium of cultural expression and influence [that] is writ large in the national narratives which construct Canada" (McKillop, 2007, p. 13). As a result of its unique properties, print media has played a role in shaping Canadian thought and culture both in the past and today.

While the above points speak to the general impact that print media can have on an audience, can such significance be ascribed to reformist print materials from turn-of-the-twentieth-century Canada? Unfortunately, there is little information which 
points toward the general societal influence of the specific publications that will be examined. However, as will be discussed, these texts existed within an information culture in which the printed word played a more essential role in Canadian thought and society than ever before (Parker, 2005, p. 17). An examination of published content on the sex trade, together with a study of the evolving information culture during the period under consideration, helps explain why and how such publications reflected, and perhaps even shaped, general attitudes toward and the treatment of female sex workers.

\section{Books on the Sex Trade}

Two books printed during this period of Canadian history which offer a reformist discourse on the sex trade are Clark's 1898 Of Toronto the Good and Shearer and Moore's 1911 Canada's War on the White Slave Traffic. Some writers of the first reform era, such as Clark, focused on female moral deviancy in their works. Other reformist authors, including Shearer and Moore, mirrored the theme of female ignorance and naïveté. In both cases, these writers promoted a behavioural interpretation of "the social evil" by holding female sex workers and their supposed character weaknesses as responsible for the trade.

Reverend J.G. Shearer and Reverend T. Albert Moore's treatise entitled Canada's War on the White Slave Traffic "became the bible of anti-white slavers in Canada and the United States" (Strange, 1995, p. 99). As discussed previously, certain sectors of society focused blame for the sex trade on women. However, not all reformers held the same beliefs. A contrasting attitude held by a number of "social purity" advocates (Strange, 1995, p. 96), including Shearer and Moore, focused on procurers as the root of "the social evil," in effect downplaying the supposed moral culpability of female sex workers (Shearer \& Moore, 1911, p. 2). Such advocates pressured police forces to focus their anti-vice efforts on men as well as women (Strange, 1995, p. 145).

Despite this somewhat more balanced view of the sex trade, reformers continued to highlight a behavioural interpretation by maintaining notions of female ignorance and naïveté. They emphasized that young women should avoid seeking independence by remaining in their family homes, as they were seen as particularly susceptible to the evil temptations of urban life (Strange, 1995, p. 97). Shearer and Moore utilize a "metaphoric representation of young women as naïve quarry," focusing primarily on innocent rural women baited by evil procurers into the trade by means of deception (Strange, 1995, p. 99). The authors do not simply highlight the 
need to focus efforts on intercepting procurers; rather they state that such measures must be undertaken as a means to protect "foolish girlhood" (Shearer \& Moore, 1911, p. 2). In what Strange (1995) has termed "the working-girl-as-dumb-animal theme" (p. 100), the authors bemoan the ease with which procurers "hunt and bait and ensnare [young women], even as the wild things of the forest are hunted, baited, and ensnared" (Shearer \& Moore, 1911, p. 5). Later, in reference to a case where a young woman was rescued from procurers by a railway official, the authors express that "One trembles to think how many similar lambs may not have thus escaped the slaughter" (Shearer \& Moore, 1911, p. 13). The content of their writing closely mirrors both the attitudes expressed by certain women's organizations, as discussed previously, and the message communicated by the fact that special officers were employed to police "naïve" young women as a means to control the sex trade.

Similar connections between print media and attitudes towards and treatment of young women and the sex trade can be found in journalist C.S. Clark's 1898 book Of Toronto the Good. As opposed to Shearer and Moore, Clark positions the male client of prostitution as the victim of female sexual delinquency (Strange, 1995, p. 94). According to Clark, "the great majority [of women who work as prostitutes] have entered from motives of pure licentiousness and at the same time to gratify a taste for an easy life" (Clark, 1970, p. 89). He continues to gesture towards the perceived moral responsibility of female sex workers by referencing scripture, quoting the following:

Hearken unto me now therefore, $O$ ye children, and attend to the words of my mouth. Let not thine heart decline to her ways, go not astray in her paths. For she hath cast down many wounded. . yea, many strong men have been slain by her. Her house is the way to hell, going down to the chambers of death (Proverbs 7: 24-27, King James Version, as cited in Clark, 1970, p. 98).

Clark cites this passage as a warning to men against "women of lewd character" (Clark, 1970, p. 98). In so doing, he places the burden of responsibility for the trade on female sex workers. This attitude parallels the message communicated by the fact that the justice system frequently penalized women charged with prostitution-related offences more heavily than men facing similar charges.

As Strange summarizes, Clark characterizes the majority of female labourers who are lured into the sex trade as morally deficient while casting male clients as innocent victims (Strange, 1995, p. 94). In doing so, "[he] essentially mouthed what police officers. . believed: working girls were inherently worthy of suspicion as moral offenders" (Strange, 1995, p. 95). The use of similar moralistic portrayals of female 
workers was common during this time period in Toronto (Rotenberg, 1974, p. 52). This characterization's close correspondence to how women were often viewed and treated by the public and the justice system demonstrates the connection that may have existed between print media and societal attitudes during Canada's first reform period.

\section{Official Publications on the Sex Trade}

Similar attitudes toward women and the sex trade are reflected in a selection of official publications from this time period, as well. Women in the trade who were not there as "white slaves," or as women who were lured by deceit into the trade (Strange, 1995, p. 99), were often portrayed as being individually responsible for their own "moral depravity." Indeed, these women were commonly depicted as responsible for the existence of the sex trade as a whole. Reluctance to recognize the economic aspect and the role of poverty in prostitution was pervasive in Canadian society (Rotenberg, 1974, p. 46). Portions of the Report of the Royal Commission on the Relations of Capital and Labor (Canada, Armstrong \& Freed, 1889) demonstrate this attitude towards women and the trade. Appointed in 1886, the commissioners visited four provinces and took evidence on the state of labour in thirty-six towns from 1,800 witnesses (Henderson, 1967a, p. 21). When asked if women's underpayment in regular employment was the driving force behind prostitution, Toronto mayor W.H. Howland responded:

I have only got to answer this - that a good woman will die first. . it is rooted laziness which is the great difficulty with those who are really prostitutes. . Take a girl when she first begins [working as a prostitute] and there may be some hope for her. . she might overcome the tendency to laziness, but with those tendencies to laziness and idleness, of course, it is almost a certainty that she will drift into such courses (Howland, November 30, 1887, as cited in Canada, Armstrong \& Freed, 1889, p. 168)

According to Howland, if a woman was driven to prostitution as a result of poverty, she was simply not working hard enough. Her employment as a provider of sexual services was therefore primarily due to defects in her character, rather than to any external forces.

Belief in the "rooted laziness" of working-class women as the source of "the social evil" was typical of many reformers (Strange, 1995, p. 35). In terms of this report, 
Howland's views most closely mirrored the views of the pro-capitalist faction of the commission that produced the minority report (Strange, 1995, p. 34). The paternalism reflected in the minority report was adopted by such organizations as the Young Women's Christian Association, Toronto's Morality Department, and juvenile and women's reformatories (Strange, 1995, p. 37). The majority report, produced by the pro-labour faction, more strongly emphasized the role of poverty in propagating the sex trade (Strange, 1995, p. 35). The contrasting tones of the minority and majority reports reflected the different attitudes towards the sex trade that took shape during this reform period (Strange, 1995, p. 37).

A similar sentiment to the one voiced by Howland is echoed in Toronto's Report of the Social Survey Commission (1915). This report states that "some [sex workers] who claimed to be unable to live decently on their wages were getting as much as the vast majority of working girls in the City manage to live on respectably" (p. 38). A woman's ability to survive on as low as $\$ 6$ per week depended on her "ability" and "training" (Toronto, 1915, p. 38). In other words, if a woman cannot make do with the low pay she receives, her personal shortcomings are the primary cause of this struggle.

This view is contrasted at various points throughout the report, when the role of poverty in often driving women into prostitution is considered with fewer qualifiers (Toronto, 1915, p. 38). However, despite these moments, the report's narrative is punctuated throughout with references to the moral dimension of the trade. This tendency upholds the vilification of female sex workers alongside the text's vague attempt at making recommendations for minimum wage measures and for consideration of the economic dimension of the trade (Toronto, 1915, p. 39). As Strange has pointed out, the mission of the Report of the Social Survey Commission was to contrast "Shearer's fables and Clark's diatribes" (Strange, 1995, p. 106) by providing a more objective and anthropological survey of the sex trade in Toronto (Strange, 1995, p. 107). However, the report recounts tales "cut from the same rhetorical cloth" as Shearer and Moore's warnings about the dangers that women flirted with by working in the city (Strange, 1995, p. 108). Similarly, the text also reproduces Clark's characterization of the working girl as an "agent," rather than an "object," of urban debauchery (Strange, 1995, pp. 107). Thus, contrary to its mission, the report, in effect, mirrored the characterizations and oversimplifications presented by the very authors that the investigators aimed to contrast.

For example, Clark's characterization is reproduced in the Toronto report when the value and "true femininity" of female sex workers is called into question. In discussing the role of procurers in the trade, the report notes that "Frequently he 
appears to be [the female sex worker's] lover, and her devotion to him - the last spark of womanliness that her degrading life has left her [emphasis added] - leads her to shield him from justice" (Toronto, 1915, p. 13). Such a statement is based on the popular ideal of the time that a properly feminine woman focuses on the concerns of domesticity - the home, her family, and supporting her husband (Vye, 2001, p. 82). To do otherwise was "un-womanly." In casting female sex workers as lacking in femininity as well as ability and training, the Toronto report and portions of the Royal Commission validated claims that female sex workers could be blamed for the trade on account of their supposed moral and behavioural deviancies. This textual treatment of prostitution closely parallels the ways that female sex workers were treated in society, hinting at some form of connection or interplay between reformist publications and public opinion.

\section{Changes in Information Culture and the Influence of Print Material}

These parallels between the printed word and lived realities can potentially be understood in terms of changes in print and information culture that strengthened Canadian society's connection with the printed word. Various developments during the period under consideration rendered such books and official publications more accessible to the general public, and therefore more able to influence the views of a greater proportion of Canadians. One of these developments was an increase in Canada's reading population. Cambron and Gerson (2005) note that, from the 1880s and 1890s onward, English-speaking writers met with greater career success on account of an expanding reading population. Contributing factors to this growth included a rising population level, improved schooling, and more leisure time (Cambron \& Gerson, 2005, pp. 128-129). By 1911, 89 per cent of Canadians over the age of five were reported as literate (Verrette, 2007, p. 453). At the end of the First World War, "the reading public...included practically all socio-economic groups" (Parker, 2005, p. 17), and by 1921 Canada was reported to have "nearly achieved full literacy" (Verrette, 2007, p. 453). These figures do not indicate how many people would have read the specific texts discussed above. However, the numbers suggest that the quantity of people who could read such publications, and other similar texts which promoted a particular social or moral agenda, was greater than in previous decades.

In addition to a growing literate population, increased rates of publication, and distribution also bolstered the ability of print material to influence Canadian society. Several developments that accompanied the industrial revolution in Canada, including steam power, new papermaking processes and, later, electronic power, 
increased the rate of production of printed materials (Parker, 2005, p. 17). The time required to produce books thus "fell from months to days" (Dewalt, 2005, p. 90). At the same time, transatlantic and railway services accelerated the speed of distribution, while lower postal rates and tariffs increased the quantity of materials that could be distributed (Parker, 2005, p. 17). The amplified production and distribution of printed materials stimulated demand, which in turn resulted in lower book prices (Dewalt, 2005, p. 90). As books became increasingly accessible and affordable, Parker notes that they became evermore "essential to an educated twentieth-century democracy" (Parker, 2005, p. 17). The fact that similarities in attitude towards the sex trade existed both on and off the page can therefore perhaps be understood in terms of the generally increasing accessibility, and therefore potential influence, of printed books.

As with books, changes in information culture and technology enabled wider publication and distribution of official publications. The presence of official publications in Canada greatly increased after Confederation, when the federal government began writing and publishing reports in large quantities (MacDonald, 2005, p. 191). The significance of official publications extended to other levels of governance, as well, as provincial and municipal governments had been the "principal publishers [in the various regions of Canada], in terms of quantity and range of materials" (Black, 2007, p. 182). With the creation of new communities, provinces, and territories, governmental influence became more widespread. Print media was therefore the most useful means for communicating with and governing this expanding jurisdiction (MacDonald, 2005, p. 188).

The purpose of official publications, and the ways in which they are compiled and reported, further highlight the relationship and potential influence that exists between these publications and the views of different groups within Canadian society. According to Henderson (1967b), two of the purposes of official commissions are "to sample public opinion on a potentially delicate political matter before legislation is introduced" and "to educate public opinion" (p.xii). The Royal Commission on the Relations of Capital and Labor reflects the former purpose in that it was based on evidence from several towns and witnesses, as discussed previously, and it was formulated in response to growing labour unrest in the 1880s (Strange, 1995, p. 28). Similarly, the Social Survey Commission was based on "exhaustive interviews with prostitutes, social workers, and refuge-home matrons" (Strange, 1995, p. 107) in response to Toronto's large social reform movement (Hunt, 2002, p. 188). The motivation behind the creation of these commissions, as well as the methods by which their contents were collected, indicates that the information they present reflects the 
thoughts of various groups within Canadian society in the late-nineteenth and earlytwentieth century.

Not only did these reports reflect common opinions and concerns, but they also served as a means to communicate specific messages to the Canadian public, as highlighted by Henderson's latter point. In order to "educate public opinion" (Henderson, 1967b, p. xii), governments must ensure that the content of their official publications are accessible to the public. To ensure this accessibility, the various Canadian social surveys of this time period created public exhibitions of their findings (Hunt, 2002, p. 186) while publicity releases and, at times, public hearings accompanied royal commissions (Henderson, 1967b, p. xiv). In addition, the government possessed its own printer, the Queen's or King's Printer, which managed the distribution of its official publications to specified libraries and institutions as well as the public (Gallichan \& MacDonald, 2007, pp. 261-262). This information does not identify how and to whom the particular reports under consideration were distributed. However, it does suggest that measures would have been enacted to ensure that Canadian citizens could be exposed to the findings in the reports, whether exposure had been through print or through public presentations and hearings.

In addition to their findings being made accessible to the public, official reports were composed of "Expert investigators [who were] implicated in power structures [such as] the state" (Strange, 1995, p. 27). The connections and professional standing of the authors therefore rendered their findings as "official bod[ies] of knowledge" on a given topic (Strange, 1995, p. 27). To its early twentieth-century audience, the authority of the Toronto report was assured by the fact that the commissioners were politicians, clergymen, representatives of social reform organizations, doctors, lawyers, businessmen, and an academic (Strange, 1995, p. 106). Similarly, the Royal Commission on the Relations of Capital and Labor was composed of sixteen commissioners appointed by the state (Strange, 1995, p. 29). The statuses of the contributors indicate that these publications were intended to offer an authoritative assessment of prostitution in Canada. This tone of authority increases the likelihood that at least a section of society would have accepted the texts' characterizations of the sex trade as valid.

The books and official publications under consideration, which sought to address and challenge the sex trade in Canada, played into the theme of personal and communal betterment which was so popular during this period (MacDonald, 2005, p. 188). Bolstered by their authoritative quality, as well as the likely distribution of their findings and relevancy to current concerns and interests, these texts were 
positioned to influence Canadian citizens. The fact that general attitudes toward, and treatment of, female sex workers often closely mirrored the ideas presented in these publications suggests, therefore, that portions of society interacted with, and were therefore in some way influenced by, the information presented in these texts.

\section{Conclusion}

The moral panic, which characterized reformist culture in late nineteenthcentury and early twentieth-century Canada, was expressed in the actions that were taken against the sex trade, as well as in print media. A tendency to question the intelligence, fortitude, and moral character of women who worked in the sex trade often overshadowed consideration of the economic dimension of the trade. Rather than being purely incidental, it is likely that these similarities in attitude both on and off the page are partially a result of print media's growing influence over Canadian thought and society.

Admittedly, this conclusion cannot yet be established with absolute certainty, as "research into the history of reading is still in its infancy" (Towheed, Crone \& Halsey, 2011 , p. 4). More direct evidence would need to be found and examined to determine more conclusively the extent to which the reformist texts under consideration influenced their readers. For example, publication numbers, book sales, and library lending records, and primary accounts of readers' reactions to, or their use of, the texts could more directly and specifically demonstrate if and how these texts shaped Canadian social thought. However, in the absence of such data, general developments in print and information culture in Canada during this period provide a potential explanation for why such close connections existed between the treatment of women who work in the sex trade both on and off the page.

The broader significance of such a study lies in its implications for today's creators and providers of published information. How might certain texts be used either to the detriment or for the support of stigmatized populations? As information professionals, how do we understand our mandate to abandon personal biases when providing access to information in light of the ethical predicament inherent in offering information that promotes a socially stigmatizing message? While no simple solution exists that can apply to every such dilemma, studies of the social impact of the printed word, both today and in history, promotes consideration of how, as providers of information, we shape society. To continually grapple with and re-examine such a consideration is essential to understanding our role in society and how to best serve our communities, and therefore essential to the advancement of the profession. 


\section{References}

Black, F.A. (2007). Prairie publishing. In C. Gerson, J. Michon, P.L. Fleming, \& Y. Lamonde (Eds.), History of the book in Canada (Vol. 3): 1918-1980 (pp. 182185). Toronto: University of Toronto Press.

Cambron, M., \& Gerson, C. (2005). Literary authorship. In Y. Lamonde, P.L. Fleming, F.A. Black (Eds.), History of the book in Canada (Vol. 2): 1840-1918 (pp. 119134). Toronto: University of Toronto Press.

Canada, Armstrong, J., \& Freed, A.T. (1889). Report of the royal commission on the relations of capital and labor in Canada (Vol. 2). Ottawa: Printed for the Queen's Printer, A. Senecal. Retrieved from http://books.google.ca/books?id=BFtZAAAAYAAJ\&pg=PP9\#v=onepage\&q\& $\mathrm{f}=\mathrm{false}$

Chunn, D. (2003). Boys will be men, girls will be mothers: The legal regulation of childhood in Toronto and Vancouver. In N. Janovicek \& J. Parr (Eds.), Histories of Canadian children and youth (pp. 188-206). Don Mills, Ont.: Oxford University Press.

Clark, C.S. (1970). The social evil. In Of Toronto the good: A social study; the queen city of Canada as it is (pp. 86-131). Montreal: The Toronto Publishing Company, 1898. [Reprint of the 1898 edition.]

Dewalt, B. (2005). Printing technology. In Y. Lamonde, P.L. Fleming, F.A. Black (Eds.), History of the book in Canada (Vol. 2): 1840-1918 (pp. 89-101). Toronto: University of Toronto Press.

Gallichan, G. \& MacDonald, B.H. (2007). Government as author and publisher. In C. Gerson, J. Michon, P.L. Fleming, \& Y. Lamonde (Eds.), History of the book in Canada (Vol. 3): 1918-1980 (pp. 261-267). Toronto: University of Toronto Press.

Henderson, G.F. (1967a). Checklist. In Federal royal commissions in Canada, 18671966: A checklist (pp. 1-184). Toronto: University of Toronto Press. 
Henderson, G.F. (1967b). Introduction. In Federal royal commissions in Canada, 18671966: A checklist (pp. xi-xvi). Toronto: University of Toronto Press.

Hunt, A. (2002). Measuring morals: The beginnings of the social survey movement in Canada, 1913-1917. Social History/Histoire Sociale, 35(69), 171-194. Retrieved from http://pi.library.yorku.ca/ojs/index.php/hssh/article/view/4488/3683

Lyons, M. (2010). What is the history of reading and writing?. In A history of reading and writing: In the Western World (pp. 1-11). Basingstoke, UK: Palgrave Macmillan.

MacDonald, B. H. (2005). To govern, inform, and persuade: Government as author. In Y. Lamonde, P.L. Fleming, F.A. Black (Eds.), History of the book in Canada (Vol. 2): 1840-1918 (pp. 186-193). Toronto: University of Toronto Press.

McCormick, C. (1995). Women who work as prostitutes: The sex trade and trading in labels. In Constructing danger: The mis/representation of crime in the news (pp. 36-55). Halifax: Fernwood Publishing.

McKillop, A.B. (2007). Imprinting the nation in words. In C. Gerson, J. Michon, P.L. Fleming, \& Y. Lamonde (Eds.), History of the book in Canada (Vol. 3): 19181980 (pp. 13-24). Toronto: University of Toronto Press.

Myers, T. (2001). The historical record and adolescent girls in Montreal's red-light district. In S.A. Cook, L.R. McLean, \& K. O'Rourke (Eds.), Framing our past: Canadian women's history in the twentieth century (pp. 228-231). Montreal: McGill-Queen's University Press.

Parker, G.L. (2005). The evolution of publishing in Canada. In Y. Lamonde, P.L. Fleming, F.A. Black (Eds.), History of the book in Canada (Vol. 2): 1840-1918 (pp. 17-32). Toronto: University of Toronto Press.

Prentice, A., Bourne, P., Brandt, G.C. Light, B., Mitchinson, W., \& Black, N. (1996). Women's sphere. In Canadian women: A history (pp. 155-188). Toronto: Harcourt Brace Jovanovich. 
Rotenberg, L. (1974). The wayward worker: Toronto's prostitute at the turn of the century. In J. Acton, P. Goldsmith, \& B. Shepard (Eds.), Women at work: Ontario, 1850-1930 (pp. 33-69). Toronto: Canadian Women's Educational Press.

Shearer, J.G., \& Moore, T.A. (1911). Canada's war on the white slave traffic. Toronto: The Department of Temperance and Moral Reform of the Methodist Church. Retrieved from http://static.torontopubliclibrary.ca/da/pdfs/191whiteslavevs.pdf

Strange, C. (1995). Toronto's girl problem: The perils and pleasures of the city, 18801930. Toronto: University of Toronto Press.

Strange, C., \& Loo, T.M. (1997). Making good: Law and moral regulation in Canada, 1867-1939. Toronto: University of Toronto Press.

Toronto. (1915). Report of the social survey commission, Toronto: Presented to the city council October $4^{\text {th }}$, 1915. Toronto: Carswell Co.

Towheed, S., Crone, R., \& Halsey, K. (2011). General introduction. In S. Towhead, R. Crone, \& K. Halsey (Eds.), The history of reading (pp. 1-8). London: Routledge.

Verrette, M. (2007). Measuring literacy. In C. Gerson, J. Michon, P.L. Fleming, \& Y. Lamonde (Eds.), History of the book in Canada (Vol. 3): 1918-1980 (pp. 453455). Toronto: University of Toronto Press.

Vye, C. (2001). Zoé Laurier, prime minister's wife: Family ideals at the turn of the century. In S.A. Cook, L.R. McLean, \& K. O'Rourke (Eds.), Framing our past: Canadian women's history in the twentieth century (pp. 82-85). Montreal: McGill-Queen's University Press. 